\title{
Heat and drought 2003 in Europe: a climate synthesis
}

\author{
Martine REBETEZ $^{\mathrm{a} *}$, Helmut MAYER $^{\mathrm{b}}$, Olivier DUPONT $^{\mathrm{c}}$, Dirk SCHINDLER $^{\mathrm{b}}$, Karl GARTNER $^{\mathrm{d}}$, \\ Jürgen P. KROPP ${ }^{\mathrm{e}}$, Anette MENZEL ${ }^{\mathrm{f}}$ \\ ${ }^{a}$ WSL Swiss Federal Research Institute, Lausanne, Switzerland \\ ${ }^{\mathrm{b}}$ Meteorological Institute, University of Freiburg, Germany \\ ${ }^{\mathrm{c}}$ MeteoFrance, Illkirch-Graffenstaden, France \\ ${ }^{\mathrm{d}}$ Federal Research and Training Centre for Forests, Natural Hazards and Landscape, Vienna, Austria \\ ${ }^{\text {e }}$ Potsdam Institute for Climate Impact Research, Potsdam, Germany \\ ${ }^{\mathrm{f}}$ Chair for Ecoclimatology, Technical University of Munich, Freising, Germany
}

(Received 14 October 2005; accepted 17 March 2006)

\begin{abstract}
Heat and drought were extreme in summer 2003 in Europe. Climatic data show that most extreme were maximum air temperatures in June and August; maps of these two months show a striking similarity in geographical range. Over wide regions, monthly mean temperatures were more than $4{ }^{\circ} \mathrm{C}$ above the long term mean values. The heat lasted from May to September in large parts of western and central Europe. The lack of precipitation was most severe in summer 2003 but precipitation was generally below normal from February 2003 until June 2004 (with the exception of two months). Sunshine duration was above normal, particularly in regions which usually have rainy and cloudy episodes in summer, and relative air humidity was below normal during the whole year of 2003. The drought experienced by the vegetation in summer 2003 was exacerbated by the length of the period with scarce precipitation and humidity, by the heat during the summer and by long sunshine duration.
\end{abstract}

climate change / drought / heat / precipitation / air temperature

Résumé - La chaleur et la sécheresse 2003 : une synthèse climatique. Températures et sécheresse ont été extrêmes en Europe durant l'été 2003. Les valeurs les plus anormales ont été atteintes par les températures maximales en juin et en août. La répartition spatiale des anomalies de température montre des similarités frappantes entre ces deux mois dans les zones les plus concernées. Des températures généralement supérieures à la normale ont régné sur une grande partie de l'Europe centrale et occidentale de mai à septembre 2003. Le déficit des précipitations a été particulièrement prononcê durant l'été 2003, mais a duré de février 2003 à juin 2004. L'insolation a été supérieure à la normale, non seulement durant l'été mais durant toute l'année 2003. La sécheresse qui a touché la végétation durant l'été 2003 a été renforcée par la durée prolongée du déficit de précipitations et d'humidité, par les températures extrêmement élevées durant l'été ainsi que des valeurs élevées d'insolation.

changement climatique / sécheresse / canicule / précipitations / températures

\section{INTRODUCTION}

Abrupt changes in frequency, location or intensity of extreme meteorological events (floods, drought, storms, etc.) have direct and severe effects on ecosystems and society, resulting in social and economic costs and even loss of life [19, $21,24]$. Climate change and the increased intensity of extreme weather events may push us to the limits of adaptive capacity in the future, and therefore increase our vulnerability. In general, it is a formidable task to estimate potential climaterelated damages and vulnerability but there exists evidence that assets located in densely populated areas could be affected most seriously $[5,6,14,18]$. Consequently, the assessment of future meteorological risks has become important to policymakers $[12,33]$. Climate synopsis and analysis of recent events can be one valuable way to reduce the deficits in our knowledge.

\footnotetext{
*Corresponding author: Rebetez@wsl.ch
}

Climate change may affect the energy, water, and nutrient balance of forest ecosystems [10, 25, 29,35]. More frequent extreme meteorological events will leave trees chronically stressed [28] and possibly more vulnerable to secondary damages $[14,36]$ like those caused by bark beetles [17].

The purpose of the present paper is to characterise the exceptional weather conditions of the summer 2003 in Europe that may directly or indirectly affect forest ecosystems. The analysis of the consequences of these meteorological conditions for forest ecosystems will be done in the following papers of this volume $[1,3,8,30]$. Here we first review the main features of the weather of summer 2003 and then we introduce complementary analyses and results useful for forest ecosystem studies.

Recent analyses show clear summer warming and drying trends in Europe in recent decades [11,18,22, 27,32]. Summer 2003 was exceptionally hot over most of central and western Europe, ranging from Spain to Hungary and from Iceland to Greece $[11,32]$. Reconstructions based on historical 
climatology data show that it was by far the hottest summer since at least $1500 \mathrm{AD}$ [16]. Based on mean surface air temperatures, the hottest region was centred over France, northern Italy, western Switzerland and Germany. June and August showed the largest deviations from mean air temperatures compared to the climate standard period (1961-1990) [11,32].

The heat was linked to persistent anticyclonic situations and exceptionally few cyclonic days from the end of June until the end of August, and in particular to an exceptionally long series of high pressure days in June and to an anomalous stabilising subsidence in August $[2,11]$. Atmospheric persistence phenomena, well-known for short-term weather states, can obviously also be observed for longer time scales [4]. These may be due to stable atmospheric circulation pattern whose occurence and duration can be increased if climate change comes true.

In the Alps, anomalous maximum air temperatures were positively correlated with sunshine duration and anomalous minimum air temperatures were negatively correlated with altitude [27]. In combination with very low precipitation [20, $31]$, the extreme air temperatures led to an exceptionally dry summer 2003 over large parts of Europe. Forest ecosystems were exposed to drought in many European countries [11]. As a complement to previous studies, we assess the intensity of the 2003 heat and drought in view of their consequences for forest ecosystems, using several climate parameters, and we compare them to previous climate series. We map mean monthly minimum air temperature and maximum air temperature anomalies for western Europe using data from the World Meteorological Organization (WMO) and Météo France. We also map sunshine duration, air humidity and precipitation anomalies. Air humidity anomalies are estimated using the French global circulation model ARPEGE [7]. Finally, we use data series from some European meteorological stations for precipitation, relative humidity, sunshine duration and PET. We compare the 2003 values for these meteorological parameters to the climate standard period $1961-1990$ or to the period 1901-2002.

\section{RESULTS}

\subsection{Temperature}

Maps of minimum and maximum air temperature (Fig. 1) show that maximum air temperature in June and in August were extremely high. Over most of Europe, they were more than $4{ }^{\circ} \mathrm{C}$ above baseline. Minimum air temperatures in June and August also reached values more than $4{ }^{\circ} \mathrm{C}$ above normal in a smaller region, mainly in the South-West, from Eastern Spain to Southern Germany, including most of continental Italy, Sardinia, Corsica, Switzerland, and most of France. August 2003 mean temperature monthly deviations reached $+6.0{ }^{\circ} \mathrm{C}$ at many weather stations in the south-west of Germany, Eastern France and Western Switzerland.

July was less extreme than June and August, except in Sweden, Finland and Norway. On most of the continent, both minimum and maximum air temperature were between 1 and $3{ }^{\circ} \mathrm{C}$ above normal. May was also generally hotter than normal and maximum air temperatures more than $4{ }^{\circ} \mathrm{C}$ above normal occurred in the South-East of Europe, from Italy to Bulgaria.

From May to August, monthly minimum and maximum air temperatures were consistently above normal from Portugal to Hungary and from Great-Britain and Denmark to Sicily and Greece. Over most of Europe, only September minimum air temperature and, for southeastern Europe only, September maximum temperature, were below average.

The similarity between the maps of maximum air temperature for June and August is striking. These two months brought extremely high air temperatures over nearly the same area of the continent.

\subsection{Precipitation}

Precipitation was particularly low in June and August (Fig. 2) but all months from May to September were dry. Across wide areas, precipitation was below average from the beginning of the year and stayed largely below the long-term normal values much later.

Freiburg, southwestern Germany, was in the relatively driest area in Europe in summer 2003 (Fig. 3). From February 2003 until June 2004, every month was drier than normal with the exception of October 2003 and January 2004.

\subsection{Sunshine duration}

A map of global radiation in summer 2003 (Fig. 4) as deviation from mean values 1996-2002, shows that most abnormal were the conditions over eastern France, Switzerland and southern Germany. Spain, western or southern France are usually very sunny during summer. They consequently show only a slight increase in summer 2003 compared to previous years. On the contrary, the North Alpine region, Switzerland, eastern France, Germany or even the mountainous region of the French Massif Central may be quite cloudy and rainy in summer. These sectors, not surprisingly, show a stronger deviation from mean sunshine duration values in summer 2003.

An analysis of potential sunshine duration (100\% potential sunshine duration corresponds to a complete absence of cloud, taking into account the length of the day depending on season, latitude and relief) for Swiss data shows that sunshine duration was above normal not only during the summer but during the entire year 2003. For example we compare 2003 with the mean values for 1901 to 2002 (Fig. 5) for two Swiss stations, Neuchatel (487 m a.s.1.) and Santis (2500 m a.s.1.). At Santis, every month in 2003 had more sunshine than normal. February and March were the sunniest months in 2003. February had sunshine during $72.2 \%$ of daylight hours in contrast to $41 \%$ in 1901 to 2002 . At a lower elevation, in Neuchatel, all months were sunnier than usual in 2003, with the exception of May and October. August had the largest number of hours of sunshine with $71 \%$ of potential, but March revealed the strongest deviation from baseline with $68 \%$ instead of $38 \%$ potential sunshine duration. 


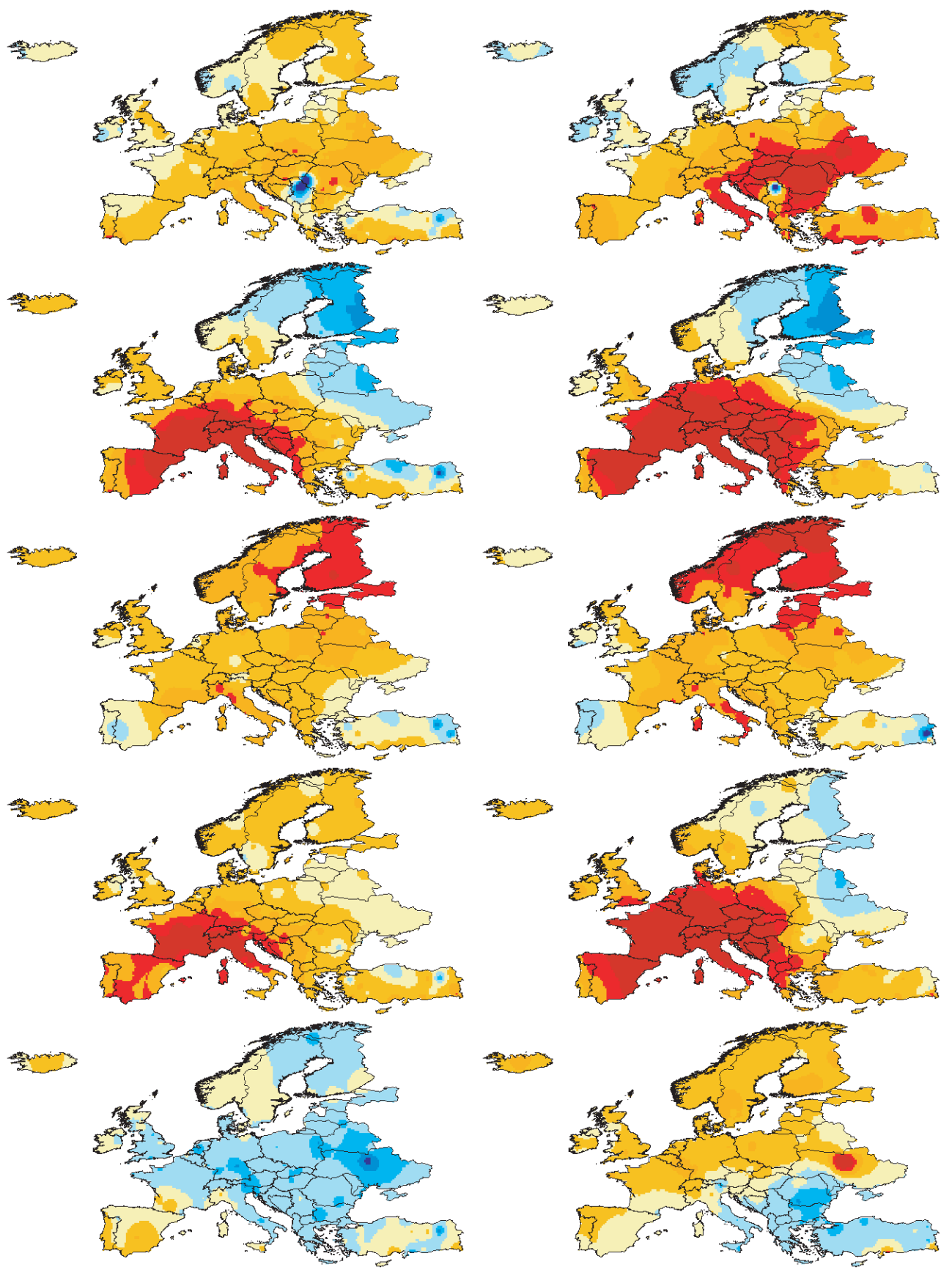

¿C

Figure 1. Monthly air temperature anomalies $\left({ }^{\circ} \mathrm{C}\right.$ ) in Europe from May (top) to September (bottom) 2003. Left: minimum air temperature; right: maximum air temperature. Anomalies are deviations from 1961-1990 monthly mean values. 


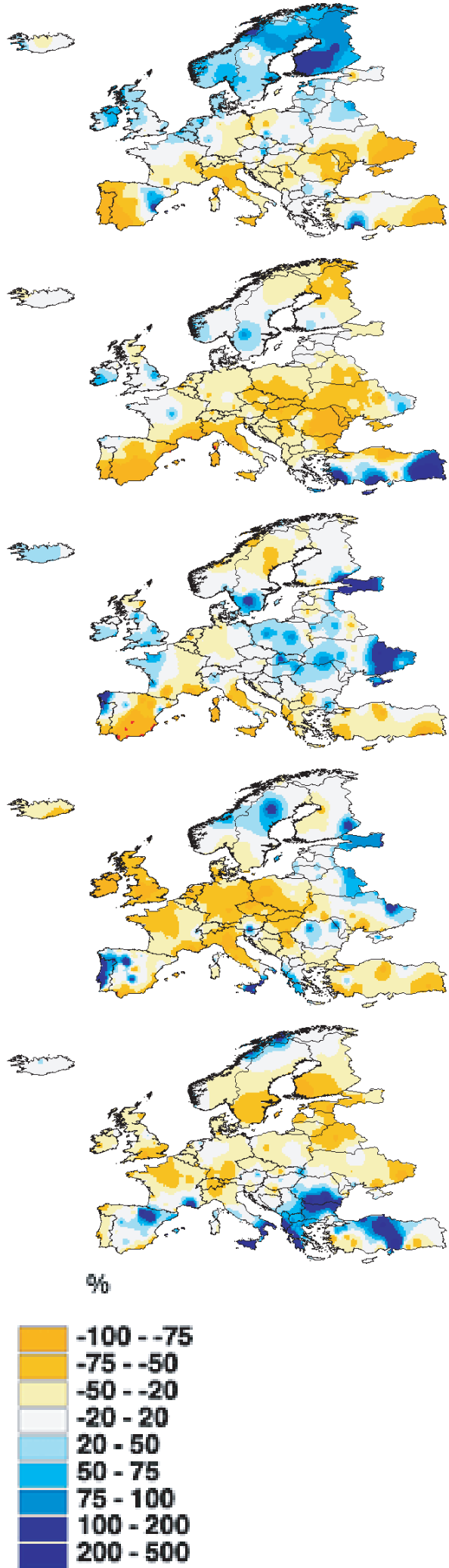

Figure 2. Monthly precipitation anomalies (\%) in Europe from May (top) to September (bottom) 2003. Anomalies are deviations from 1961-1990 monthly mean values (100\%).

\subsection{Relative humidity}

Relative humidity was clearly below normal in summer 2003. In some areas, ARPEGE model results showed more than 60 days with a minimum humidity value below the 10th percentile when compared to the reference period 1998-2002 (Fig. 6). Large regions had more than 40 days below the 10th percentile. Data for the whole year at two stations in the most strongly affected area (Fig. 7) show that low relative humidity was not restricted to the summer period. Mean monthly relative humidity was below normal for all months, at both high and low elevation with the single exception of November at low elevation.

\subsection{Potential evapotranspiration (PET)}

Potential evapotranspiration was clearly above normal in summer 2003. We compared PET in 2003 and 2004 for the station of Freiburg and computed (Fig. 8) the climatic water balance (CWB), i.e. the difference between daily values of precipitation and PET according to Haude [9]. The deficit in 2003 compared to 2004 starts in the beginning of May, increases strongly until August and does not decrease until the end of the year.

\section{DISCUSSION}

Our results confirm the exceptional character of the meteorological conditions in summer 2003. They show that it was extremely sunny, dry and hot. Minimum and maximum temperatures were both clearly above normal during that summer, but the anomalies were largest for maximum temperatures in June and August. Hot conditions were not restricted to the three summer months but the whole period of May to September was generally abnormally warm in central and western Europe. Other meteorological parameters were extreme for even longer times. Sunshine duration was above normal during the entire year with late winter (February and March) already showing extremely high relative values compared to long-term norms. Precipitation and relative humidity were below normal during the whole year, with the exception of October or November, respectively. Precipitation remained low until mid2004. PET, compared to 2004 values, has been low since the beginning of May 2003.

Previous studies have shown that, in general, minimum air temperatures have increased more than maximum air temperatures during the 20th century $[13,26]$. In summer 2003, however, maximum air temperatures appear to have departed more strongly from the long-term mean values than minimum air temperatures.

Air temperatures over Europe were indeed exceptionally high in summer 2003, but they were less so compared to air temperatures recorded in the last few decades, due to a strong increase in the number of hot summer days [22, 27]. From a global perspective, the ten warmest years were recorded after 1990 and the 1990' were clearly the hottest decade of 
Freiburg

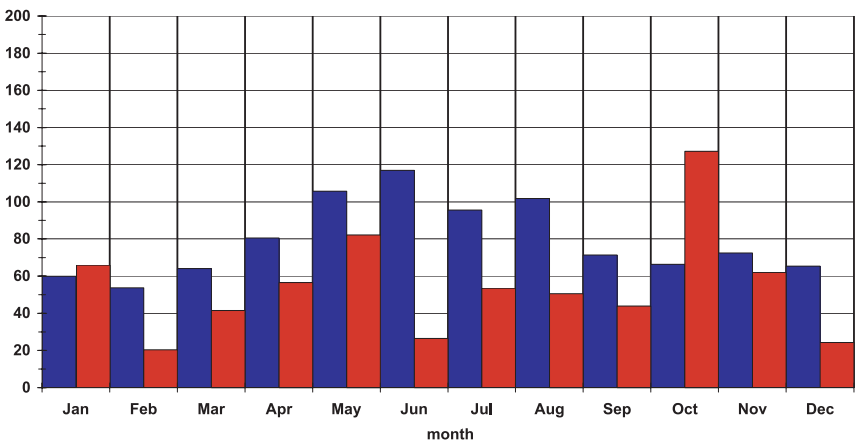

Freiburg

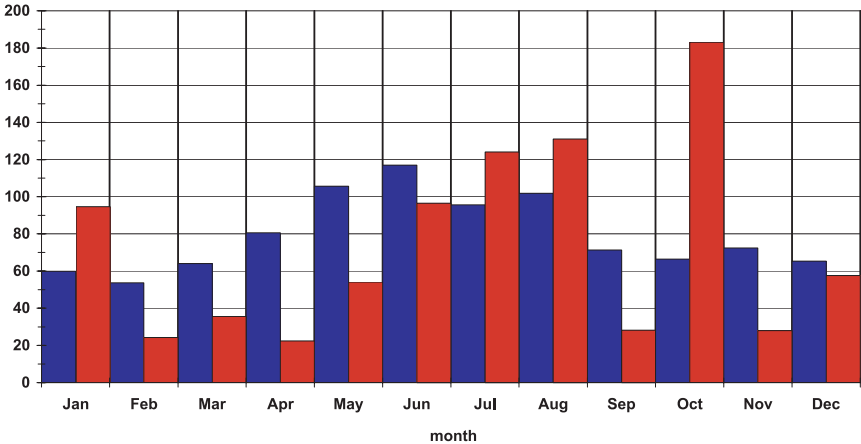

Figure 3. Monthly precipitation (mm) in Freiburg (Southwestern Germany), 269 m a.s.l., in 2003 (left) and 2004 (right) in red compared to reference mean values 1961-1990 (in blue).

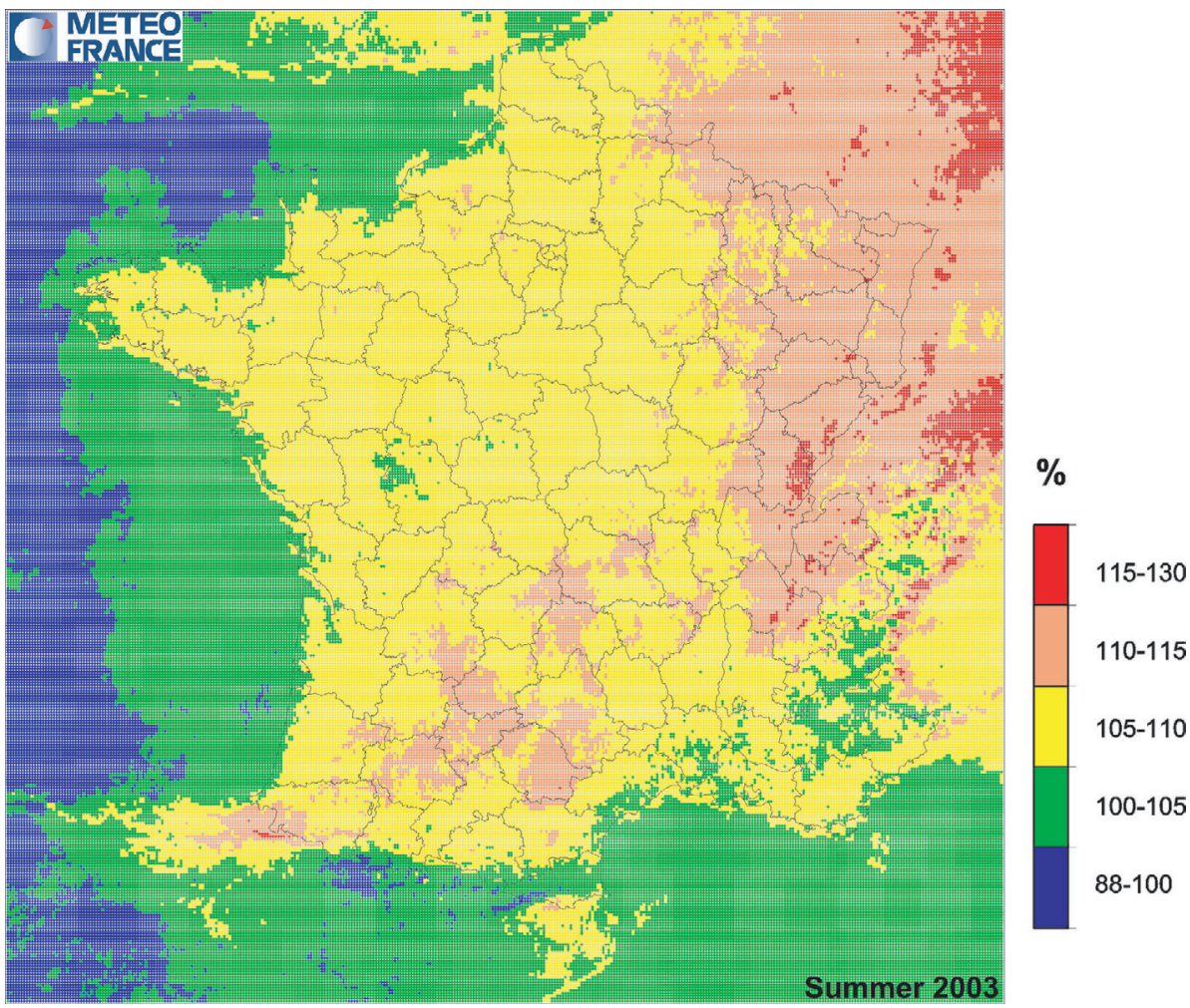

Figure 4. Map of global radiation from June to August 2003 as deviations from 1996-2002 mean values; computed from Meteosat data.

the century [23]. The number of summer days with an air temperature exceeding $30{ }^{\circ} \mathrm{C}$ and the number of dry summer days is expected to continue to increase during the 21 st century $[11,32]$. Human influence has at least doubled (confidence level > 90\%) the risk of a heat wave like that of 2003 [34].

It is highly probable that the same persistent anticyclonic conditions as in 2003 would not have brought such high temperatures without global climate change. The conditions prevailing in summer 2003 can thus be considered to be a result of the combination of global warming and exceptional pressure conditions over Europe and the North Atlantic.

The drought can be expected to have particularly important consequences as it was not limited to a short period of the year.
The drought lasted longer than just summer 2003 and even longer than just 2003. Although there was more precipitation in autumn, the deficit actually lasted for 18 months with an acute episode in summer 2003.

From a climatic point of view, the unusual weather in summer 2003 can be expected to have a strong impact on forest ecosystems as plant evaporation and transpiration during a drought episode depend both on the moisture availability at onset and on drought severity and duration. Although transpiration may decrease during the episode (e.g. by leaf curling or leaf shedding) as plants attempt to conserve water, this selfregulation is limited. 

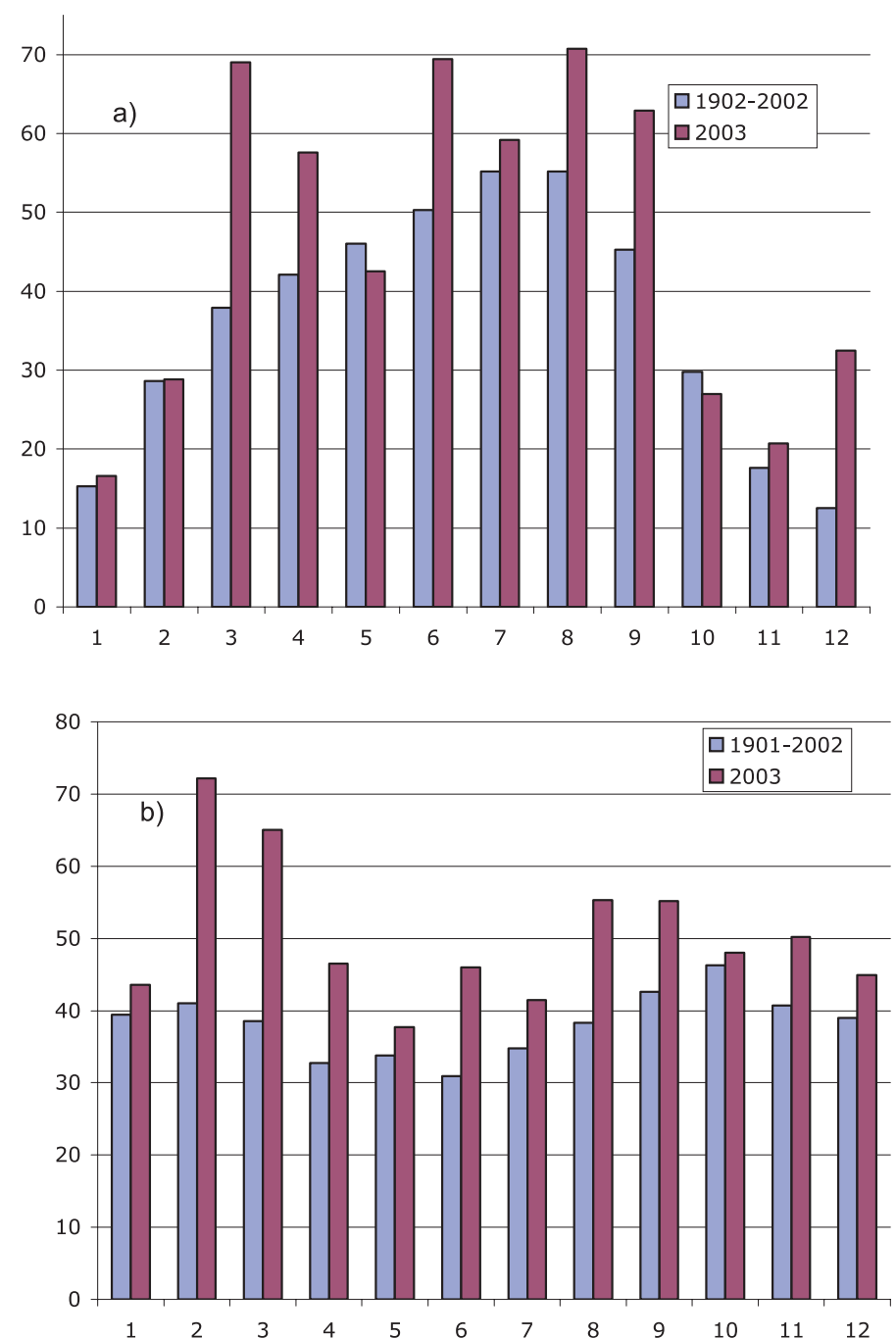

Figure 5. Monthly sunshine duration (\%) in 2003 compared to mean values 1901-2002 for (a) Neuchatel (Switzerland), $487 \mathrm{~m}$ a.s.1., and (b) Santis (Switzerland), $2500 \mathrm{~m}$ a.s.l.

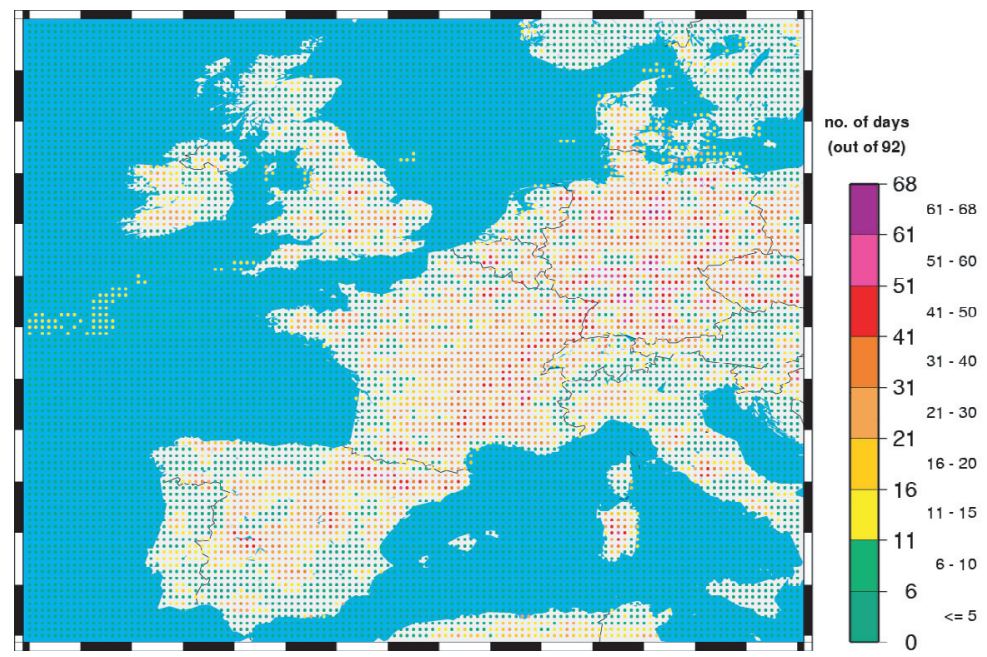

Figure 6. Number of days with minimum relative humidity below the tenth percentile, compared to the reference period 1998-2002, as estimated by the French global circulation model ARPEGE. 

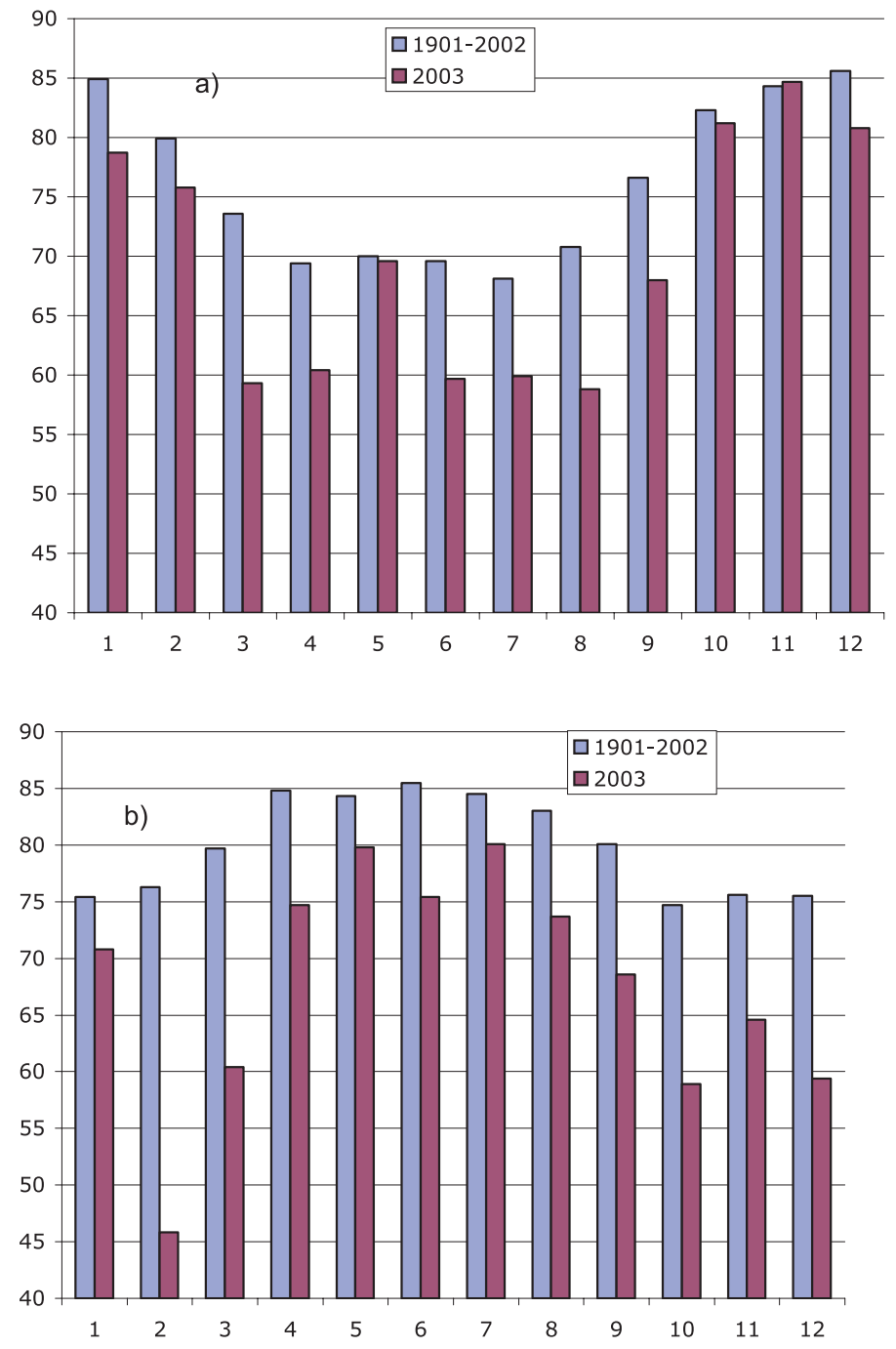

Figure 7. Monthly relative humidity in 2003 compared to mean values 1901-2002 for (a) Neuchatel (Switzerland), 487 m a.s.1., and (b) Santis (Switzerland), $2500 \mathrm{~m}$ a.s.l.

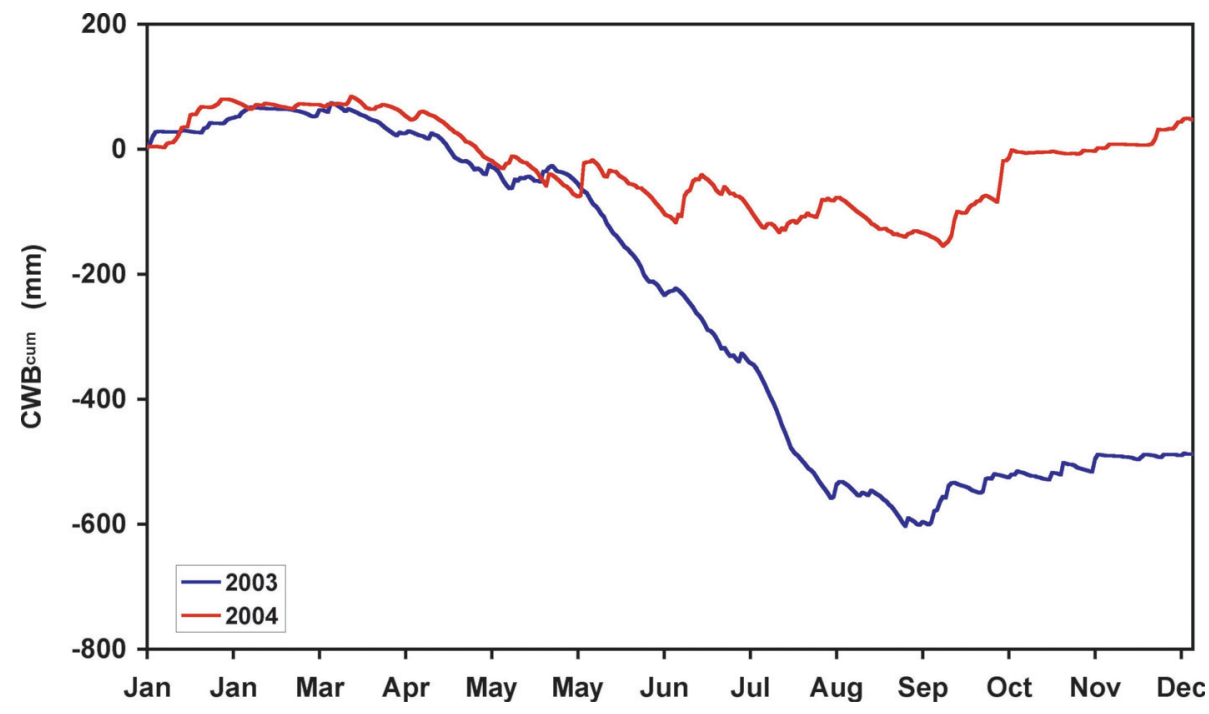

Figure 8. Climatic water balance (CWB) according to Haude [9] in Freiburg (Germany) in 2003 and 2004. 
The drought experienced by the vegetation was long and strong. It was increased by the exceptionally high air temperatures during summer 2003, and by the high sunshine duration, which reinforced evaporative stress. We suggest that analyses of the consequences of the 2003 drought on ecosystems should take high air temperatures, strong sunshine duration and low relative humidity into consideration as well as the low precipitation.

\section{CONCLUSION}

Weather data from 2003/2004 showed an acute drought in summer 2003, but also that drought conditions have occurred over a much longer time. At least in some regions, including the relatively hottest places during summer 2003 (eastern France, Switzerland and Southern Germany) drought was most severe in June and August and extended to June 2004. This series of 17 months with scarce precipitation was only briefly interrupted, in October and January. Sunshine duration was also extremely high and relative humidity extremely low during the whole year of 2003. Every month brought more sunshine than normal. February and March were particularly sunny compared to long-term mean values. Departure from normal sunshine duration values was strongest in regions which may usually have partly rainy and cloudy summers.

Air temperatures were most abnormal in June and August over an extremely wide geographical area with monthly anomalies of up to $6{ }^{\circ} \mathrm{C}$ in a large part of Europe. Maximum temperature anomalies were higher than minimum temperatures.

Analyses of the consequences on forest ecosystems should take into account the exceptional length and strength of the drought. They should also consider the fact that the exceptionally high air temperatures during summer 2003 reinforced the drought stress for the vegetation.

Acknowledgements: This work has been supported in part by the Forest Investigation Program, a joint project between the Swiss Federal Office for the Environment (FOEN) and the Swiss Federal Institute for Forest, Snow and Landscape Research (WSL). We are grateful to MeteoSwiss, Meteo-France and the German Weather Service for the meteorological data, to Fawziah Gadallah for her useful suggestions and assistance with English, to Guy Landmann and to Erwin Dreyer for their constructive comments and suggestions.

\section{REFERENCES}

[1] Archaux F., Wolters V., Impact of summer drought on forest biodiversity: what do we know, Ann. For. Sci. 63 (2006) 643-650.

[2] Black E., Blackburn M., Harrison G., Hoskins B., Methven J., Factors contributing to the summer 2003 European heatwave, Weather 59 (2004) 217-223.

[3] Breda N., Huc R., Granier A., Dreyer E., Temperate forest trees and stands under severe drought: a review of ecophysiological responses, adaptations and consequences, Ann. For. Sci. 63 (2006) 623-642.

[4] Bunde A., Havlin S., Koscielny-Bunde E., Schellnhuber H., Atmospheric Persistence Analysis: novel approaches and applications, in: Bunde A., Kropp J., Schellnhuber H. (Eds.), The
Science of Disasters: Climate Disruptions, Heart Attacks and Market Crashes, Springer, Berlin, 2002.

[5] Changnon S.A., Economic impacts of climate conditions in the United States: Past, present, and future - An editorial essay, Clim. Change 68 (2005) 1-9.

[6] Changnon S.A., Pielke R.A., Changnon D., Sylves R.T., Pulwarty R., Human factors explain the increased losses from weather and climate extremes, Bull. Am. Meteorol. Soc. 81 (2000) 437-442.

[7] Courtier P., Freydier C., Geleyn J.F., Rabier F., Rochas M., The ARPEGE project at Meteo-France, Proc. ECMWF Seminar on Numerical Methods in Atmospheric Models, 9-13, September 1991, Vol. II, 192-231.

[8] Desprez-Loustau M.L., Marcais B., Nageleisen L.M., Piou D., Vanini A., Interactive effects of drought and pathogens in forest trees, Ann. For. Sci. 63 (2006) 595-610.

[9] DIN-VDI, Klimatische Standortuntersuchung - Ermittlung der meteorologischen Grössen, Paderborn, BeuthVerlag, 1997, 252 p.

[10] Dobbertin M., Hilker N., Rebetez M., Zimmermann N., Wohlgemuth T., Rigling A., The upward shift in altitude of pine mistletoe (Viscum album ssp. austriacum) in Switzerland - the result of climate warming? Int. J. Biometeorol. 50 (2005) 40-47.

[11] Fink A., Brucher T., Kruger A., Leckebusch G., Pinto J., Ulbrich U., The 2003 European summer heatwaves and drought - synoptic diagnosis and impacts, Weather 59 (2004) 2009-2216.

[12] IPCC, Climate change 2001: Mitigation, Vol. 3, Cambridge University Press, Cambridge, UK, 2002.

[13] Karl T.R., Jones P.D., Knight R.W., Kukla G., Plummer N., Razuvayev V., Gallo K.P., Lindseay J., Charlson R.J., Peterson T.C., A new perspective on recent global warming - Asymmetric trends of daily maximum and minimum temperature, Bull. Am. Meteorol. Soc. 74 (1993) 1007-1023.

[14] Kropp J., Block A., Reusswig F., Zickfeld K., Schellnhuber H., Semiquantitative Assessment of Regional Climate Vulnerability: The North-Rhine Westphalia Study, Clim. Change (2006) (in press).

[15] Kunkel K.E., Pielke R.A., Changnon S.A., Temporal fluctuations in weather and climate extremes that cause economic and human health impacts: A review, Bull. Am. Meteorol. Soc. 80 (1999) 10771098

[16] Luterbacher J., Dietrich D., Xoplaki E., Grosjean M., Wanner H., European seasonal and annual temperature variability, trends, and extremes since 1500, Science 303 (2004) 1499-1503.

[17] Malmstrom C.M., Raffa K.F., Biotic disturbance agents in the boreal forest: considerations for vegetation change models, Glob. Change Biol. 6 (2000) 35-48.

[18] Mayer H., Holst T., Brugger U., Kirchgäßner A., Trends der forstlich relevanten Klimavariablen Luftemperatur und Niederschlag im Südwesten Deutschlands von 1950 bis 2000, Allg. Forst- u. J.-Ztg. 176 (2005) 45-56.

[19] Meehl G.A., Karl T., Easterling D.R., Changnon S., Pielke R., Changnon D., Evans J., Groisman P.Y., Knutson T.R., Kunkel K.E., Mearns L.O., Parmesan C., Pulwarty R., Root T., Sylves R.T., Whetton P., Zwiers F., An introduction to trends in extreme weather and climate events: Observations, socioeconomic impacts, terrestrial ecological impacts, and model projections, Bull. Am. Meteorol. Soc. 81 (2000) 413-416.

[20] Müller-Westermeier G., Riecke W., Die Witterung in Deutschland 2003, Climate Status Report 2003, German Weather Service, Offenbach (2004).

[21] Murnane R.J., Climate research and reinsurance, Bull. Am. Meteorol. Soc. 85 (2004) 697-707.

[22] Pal J.S., Giorgi F., Bi X.Q., Consistency of recent European summer precipitation trends and extremes with future regional climate projections, Geophys. Res. Lett. 31 (2004) L13202.

[23] Parker D.E., Alexander L.V., Kennedy J., Global and regional climate in 2003, Weather 59 (2004) 145-152. 
[24] Parmesan C., Root T.L., Willig M.R., Impacts of extreme weather and climate on terrestrial biota, Bull. Am. Meteorol. Soc. 81 (2000) $443-450$.

[25] Parmesan C., Yohe G., A globally coherent fingerprint of climate change impacts across natural systems, Nature 421 (2003) 37-42.

[26] Rebetez M., Changes in daily and nightly day-to-day temperature variability during the twentieth century for two stations in Switzerland, Theor. Appl. Climatol. 69 (2001) 13-21.

[27] Rebetez M., Summer 2003 maximum and minimum daily temperatures over a $3300 \mathrm{~m}$ altitudinal range in the Alps, Clim. Res. 27 (2004) 45-50.

[28] Rebetez M., Dobbertin M., Climate change may already threaten Scots pine stands in the Swiss Alps, Theor. Appl. Climatol. 79 (2004) 1-9.

[29] Rigling A., Braker O., Schneiter G., Schweingruber F., Intraannual tree-ring parameters indicating differences in drought stress of Pinus sylvestris forests within the Erico-Pinion in the Valais (Switzerland), Plant Ecol. 163 (2002) 105-121.
[30] Rouault G., Candeau J.N., Lieutuer F., Martin J.C., Grégoire J.C., Nageleisen L.M., Landmann G., Effect of drought and heat on forest insect populations in relation to the 2003 drought in Western Europe, Ann. For. Sci. 63 (2006) 611-622.

[31] Rudolf B., Zeitlich-räumliche Verteilung der Gebietsniederschläge in Europa, Climate Status Report 2003, German Weather Service, Offenbach, 2004

[32] Schaer C., Vidale P.L., Luthi D., Frei C., Haberli C., Liniger M.A., Appenzeller C., The role of increasing temperature variability in European summer heatwaves. Nature 427 (2004) 332-336.

[33] Schnur R., Climate science: The investment forecast, Nature 415 (2002) 483-484.

[34] Stott P.A., Stone D.A., Allen M.R., Human contribution to the European heatwave of 2003, Nature 432 (2004) 610-614.

[35] Wellpott A., Imbery F., Schindler D., Mayer H., Simulation of drought for a Scots pine forest (Pinus sylvestris L.) in the southern upper Rhine plain, Meteorol. Z. 14 (2005) 143-150.

[36] Wilson J., Vulnerability to wind damage in managed landscapes of the coastal Pacific Northwest, For. Ecol. Manage. 191 (2004) 341351. 